\title{
Data and knowledge gaps in glacier, snow and related runoff research - A climate change adaptation perspective
}

\author{
Nadine Salzmann $^{\mathrm{a}, \mathrm{b}, *}$, Christian Huggel ${ }^{\mathrm{b}}$, Mario Rohrer ${ }^{\mathrm{c}}$, Markus Stoffel ${ }^{\mathrm{d}, \mathrm{e}}$ \\ a Department of Geosciences, University of Fribourg, Chemin du Musée 4, 1700 Fribourg, Switzerland \\ ${ }^{\mathrm{b}}$ Department of Geography, University of Zurich, Winterthurerstr. 190, 8057 Zurich, Switzerland \\ ${ }^{\mathrm{C}}$ Meteodat GmbH, Technoparkstr. 1, 8005 Zurich, Switzerland \\ ${ }^{\mathrm{d}}$ Institute for Environmental Sciences, University of Geneva, Chemin de Drize 7, CH-1227 Carouge, Geneva, Switzerland \\ ${ }^{\mathrm{e}}$ Dendrolab.ch, Institute of Geological Sciences, University of Bern, Baltzerstrasse 1+3, CH-3012 Bern, Switzerland
}

\begin{abstract}
Glacier and snow cover changes with related impacts on melt runoff can seriously affect human societies which are depending on fresh water from cryospheric sources. Observed trends and projected future evolutions of climatic and cryospheric variables clearly show the need to adapt to these changes. Accordingly, the topics addressed herein have been put on the agendas of many larger funding agencies. This article provides a brief overview on major ongoing activities on glacier, snow and related runoff research in order to then analyze data gaps and research needs from a climate change adaptation perspective. Major data needs are identified with respect to the spatial and temporal coverage of local-scale data and related needs for (data) services that distribute and maintain these data sets. Moreover, clear research needs are also recognized at the local scale where process knowledge needs to be improved (e.g., the influence of albedo on snow and ice or debris cover on glaciers) in order to derive plausible climate change impacts assessments. The paper then discusses directions on how to move forward to better serve the practical needs for climate change adaptation planning. In the future, substantial support by large funding agencies might be key for capacity building in target regions of climate change adaptation programs, for longer-term and more sustainable commitments, and for the development of approaches, which aim at assessing the transferability of data, techniques, and tools.
\end{abstract}

\section{Introduction}

Glaciers and seasonal snow cover in mountain areas are an important component of the water cycle and the climate system (Barnett et al., 2005). They supply a significant part of the water resources for fresh water, irrigation or power production in mountain regions and adjacent lowlands, particularly in arid or semiarid environments (Viviroli et al., 2007). In the Colorado Rocky Mountains, for instance, high elevation snow pack provides about $70 \%$ of the annual runoff of the Colorado River and the seasonal runoff pattern is heavily dominated by winter snow accumulation and spring melt (Christensen et al., 2004). In the tropical Andes, with their distinct wet-dry climate, glacierized mountain ranges such as the Cordillera Vilcanota (Southern Peru) play a significant role in providing water from glacier melt during the dry period

* Corresponding author at: Department of Geosciences, University of Fribourg, Chemin du Musée 4, 1700 Fribourg, Switzerland. Tel.: +41 2630092 50; fax: +41 26 3009746 .

E-mail address: nadine.salzmann@unifr.ch (N. Salzmann). for irrigation, power production and fresh water supply, and are thus an important socio-economic factor (Vergara et al., 2007). In the headwaters of the Ganges, river flow variation has been shown to be driven by the summer monsoon. As a consequence, much of the discharge reductions since the 1960 s (by $50 \%$ in the lower Sutlej and north-west Ganges basin) were caused by a weakening monsoon - with a related decrease in the temporary water storage in the form of snow - but less so by melting glaciers (Collins et al., 2013).

Mountain glaciers and snow are particularly sensitive to climatic changes because of their proximity to melt conditions. As air temperature is a major index for ice and snow melt processes (e.g., Hock, 2003), the observed and projected rise in global mean air temperature cause overall significant losses of ice masses worldwide (IPCC, 2013), an effect which is either damped or enhanced by changes in regional precipitation patterns. A large number of in situ and satellite based observations provides evidence of the global-scale shrinkage of mountain glaciers (Gardner et al., 2013). Similarly, various monitoring studies indicate a decline in snow cover extent in most months, and in 
particularly in spring (Déry and Brown, 2007), since the early 20th century (Brown and Mote, 2009; Henderson and Leathers, 2010; Marty, 2008; Voigt et al., 2011). Since snow cover is a seasonal phenomenon, its spatial variability is accordingly much higher than for glaciers. For the future, modeling studies at various temporal and spatial scales and degrees of complexity consistently suggest a strong decrease in glacier extent, ice volume, and snow cover extent and duration (Huss et al., 2008; Marzeion et al., 2012; Salzmann et al., 2012; Brutel-Vuilmet et al., 2013).

The contribution of glaciers to downstream runoff depends on glacier size, proportion of glacier area to catchment size, and seasonal climatic conditions. There is substantial concern that warming will have a negative effect on freshwater supply, hydropower production and other eco-services (Finger et al., 2012; Huss et al., 2014). In fact, for some catchments in the Andes of Peru or the Alps, 'peak water', i.e. the point in time when runoff starts to decline, has probably already passed, based on documented longterm runoff monitoring (Collins, 2006; Baraer et al., 2012).

Changes in seasonality of runoff will also be significantly influenced by snow cover and related modifications due to climatic changes. Combined effects of glacier and snow cover changes will thus exacerbate shifts in seasonality of runoff. The importance of snow cover on the availability and timing of runoff in the Greater Himalayas has been outlined recently by Rohrer et al. (2013). Water supply in the Greater Himalayas often strongly depends on the sub-region and even on the particular watershed, as can be illustrated by the example of two villages in Mustang (Nepal). The people of these two villages heavily depend on the highly variable and increasingly reduced runoff from snow cover. As a consequence of seriously felt changes, both villages have now decided to move down-valley to locations where water provision is more diversified. A third village in the same Himalayan valley has considered searching for a new location as well, but finally decided that water resources are still sufficient, at least for the time being (Kamforsud-Supsi, 2012).

These considerations and experiences clearly signal the need for mountain and downstream societies to respond and adapt to changes of water resources. The increasing number of climate change adaptation programs with a clear focus on water resources (e.g. PACC (Salzmann et al., 2009; IH-CAP (http://www.ihcap.in); CAWa (Vorogushyn et al., 2008) clearly demonstrate that the challenge has been understood and is being addressed at high political levels. However, while there is a clear observed and projected global trend of increasing air temperature, the pattern for precipitation is less consistent (Fig. 1) and at regional to local scales also the magnitude of air temperature increase can vary considerably, particularly in regions with distinct high-elevation topography (Schauwecker et al., 2014). In combination with differences in the climate sensitivities of earth surface processes, the effective impacts can vary significantly as illustrated by Fig. 2, which shows the observed cumulative changes in glacier mass balance of selected glaciers of the Swiss Alps. This fact of high spatial and temporal variability of key climate variables and physical impacts is a serious drawback for adaptation efforts, since it underlines the need for data and knowledge to be available at the local scale, in addition to the development of adequate adaptation measures within the local socio-economic context.

This article aims at providing a general overview on directions and recent progress in glacier, snow and related runoff research as often supported by major funding institutions such as the European Commission (under its past Seventh Framework Programme or now in Horizon 2020), the World Bank, or governmental development agencies (e.g., Swiss Agency for Development and Cooperation SDC). Rather than addressing issues related to fundamental research, we are adopting a perspective of needs for climate change adaptation measures to be developed. Thus, we strive (i) to analyze how progress in data acquisition, management and research is supportive for the development of adaptation measures, (ii) to identify research and data gaps in view of adaptation needs, and (iii) to discuss possible ways to move forward. Consequently, we are far from aspiring a comprehensive state-of-the-art analysis or review of monitoring, research and data gaps in the fields of glacier and snow runoff. Rather, we select a number of key issues that are relevant from a climate impacts and adaptation perspective, including selected examples from different mountain regions of the world.

\section{General overview and selected examples of glacier, snow and runoff research}

Adverse impacts associated with a decrease of snow and ice and the related changes in melt runoff can affect societies seriously (Barnett et al., 2005; Beniston et al., 2011; Viviroli et al., 2011). International programs (e.g. UNEP, WMO under the Global Terrestrial Network GTN) and funding agencies (e.g. EU, World Bank) have responded to these challenges with a multitude of research programs and funding schemes dedicated to glacier and snow research. In the following, we provide a brief overview in the form of selected examples from large research programs in glacier and snow runoff research without attempting to being comprehensive or to including all major ongoing initiatives.

\subsection{Glaciers}

As glaciers are among the most obvious, because most clearly visible indicators of climate change, great efforts have been put into global glacier monitoring programs in the past. While some of these programs have been running for several decades (e.g. World Glacier Monitoring Service, WGMS), others started more recently (e.g. Global Land Ice Measurements from Space, GLIMS) and when new methods and techniques became available. These programs complement each other in terms of monitored variables, spatial coverage and applied methods.

Some of the longest records of standardized glacier mass balance measurements and length changes are compiled and disseminated by the WGMS. The data is based on standardized in situ measurement methods such as stake networks, and is disseminated online and in the form of printed products (e.g. Glacier Mass Balance Bulletin (GMBB) or Fluctuations of Glaciers (FOG)). From Fig. 3, it becomes obvious that the observed glaciers are not evenly distributed in space. In particular, regions with high vulnerabilities to glacier change (IPCC, 2013), such as the Andes (cf. Fig. 6) or Central Asia dispose only of a limited number of long-term observational records, whereas the Alps have a fairly dense network of long observation series.

The aforementioned in situ monitoring measurements are complemented by data from optical satellite instruments. GLIMS provides worldwide glacier outlines and collects the corresponding satellite scenes, mainly from ASTER imagery. The data products offered by GLIMS have recently been supplemented by the new and freely available global glacier inventory, the Randolph Glacier Inventory (RGI; Arendt et al., 2012), an initiative that was considerable supported by the GlobGlacier, Glacier_cci (funded by ESA; Paul et al., in press), Cryoclim (funded by ESA), and ice2sea (funded by the EU FP7 program) projects. The compilation of the RGI was motivated by the release of the Fifth Assessment Report of the Intergovernmental Panel on Climate Change (IPCC AR5). RGI provides worldwide glacier outlines based on various data sources such as satellite data, dating back to the 1950s, or the World Glacier Inventory (WGI) dataset, and includes data until 2010. In that sense, and in difference to some other, more regional products, the RGI does not represent the state of glaciers for a certain point in time or a specific decade. 


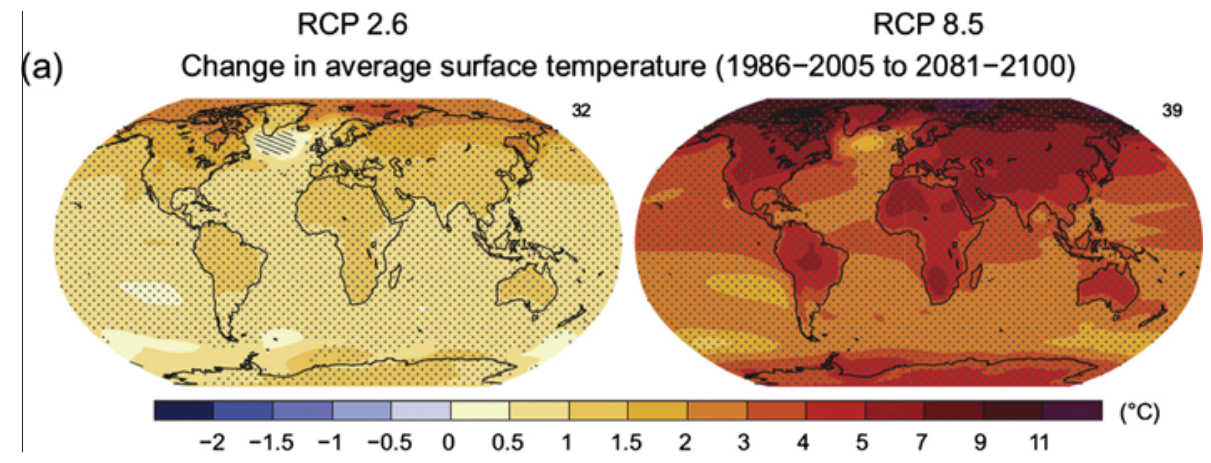

(b)

Change in average precipitation (1986-2005 to 2081-2100)

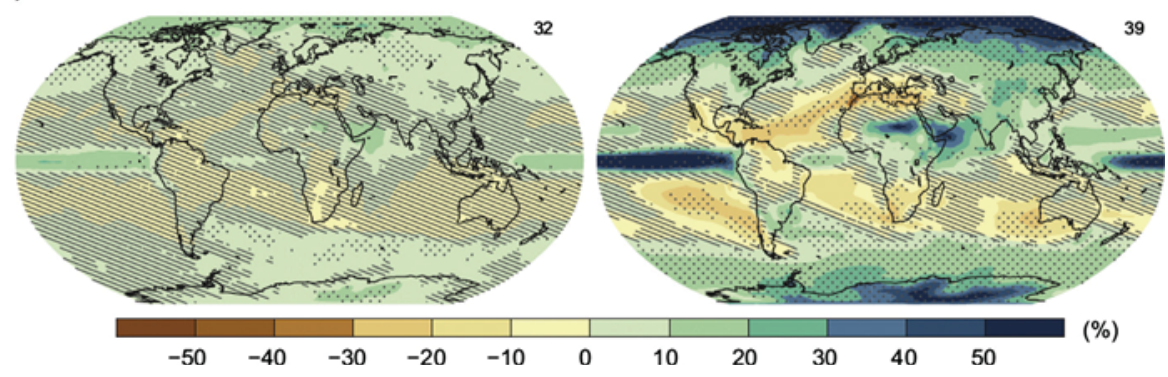

Fig. 1. Global pattern of average changes in air temperature and precipitation based on CMIP5 multi-model mean results for two different scenarios (RCP2.6 and RCP8.5). Source: IPCC (2013)

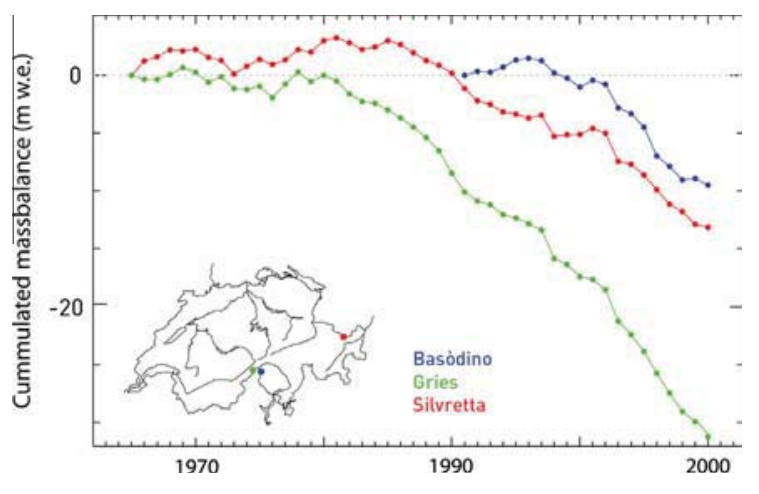

Fig. 2. Observed glacier mass balance changes of three glaciers in the Swiss Alps. (Source: GLAMOS)

Programs and projects such as GLIMS or GlobGlacier/Glacier_cci were in the first place based on optical satellite remote sensing data such as the widely used Landsat TM images, but have also incorporated synthetic aperture radar (SAR) data more recently (Paul et al., in press; Strozzi et al., 2008). Furthermore, laser altimetry data, both airborne and spaceborne, have also gained increasing importance for mountain glaciers over the past few years. An early study was using airborne altimetry analyzed elevation changes for glaciers in Alaska (Arendt et al., 2002). Later on, analysis of the laser altimetry data on board ICESat has allowed, for instance, new insights into glacier mass changes over the Himalayas (Kääb et al., 2012). Additionally, data from the Gravity Recovery and Climate Experiment (GRACE) has recently been analyzed for larger mountain systems, in addition to the more common applications over the ice sheets. Experiences with GRACE such as for Gulf of Alaska glaciers (Arendt et al., 2013) or on a global scale (Jacob et al., 2012) indicate an interesting potential of gravity data but also revealed difficulties of application in complex topography and terrain as often present in mountain environments.
The data products of the above mentioned programs have been used in various applications. A prominent application is the use of the RGI for global assessments of glacial contribution to sea level rise (e.g., ice2sea). Partly also in the course of these studies, several approaches have been developed to estimate glacier volumes. Ice volume methods have mostly been compared between each other and less with measured ice thickness data, since such measurements are scarce and availability limited on a global scale (e.g. Frey et al., 2013; Huss and Farinotti, 2012).

A series of large-scale integrating EU-FP7 projects have addressed glacier changes at the more regional level. The ACQWA project, for instance, has focused on glacier changes in the Alps, the Chilean Andes (Aconcagua) and the Tian Shan mountains of Central Asia as well as the impacts of their melting and snow cover changes on runoff (Pellicciotti et al., 2014a, b). In dry northern Tian Shan, melting glaciers are currently producing "peak water", but discharge is likely to decrease substantially by the end of the century and in an area which is not only crucial for water availability in Bishkek, but also for political stability in a much larger region (Sorg et al., 2012; in press). The EU-FP7 HighNoon project focused on changing water resources in the Ganges, where glacier observation data is extremely scarce and where meteorological and hydrological time series are not readily available. One of the key foci of the HighNoon project therefore consisted in the creation of the first full dataset on Hindukush-Karakoram-Himalayan glaciers (Bolch et al., 2012; Fig. 5), their volumes (Frey et al., 2013) and the consequences that changes in runoff might have on downstream economies and the adaptive capacity of local inhabitants (Collins et al., 2013; Moors and Stoffel, 2013).

At the local scale, glacier studies are generally often motivated by acute glacier-related hazards and risks (e.g. GLOFs in Huaraz, Huggel et al., 2012 or the Indian Himalayas, Worni et al., 2013), economic interests (e.g., hydropower production in the Alps) or simply by specific research interests of a research group (e.g. Machguth et al., 2006). As a result, these local studies are usually funded by local governments, private companies or national funding agencies and thus suffer the drawback of limited project 


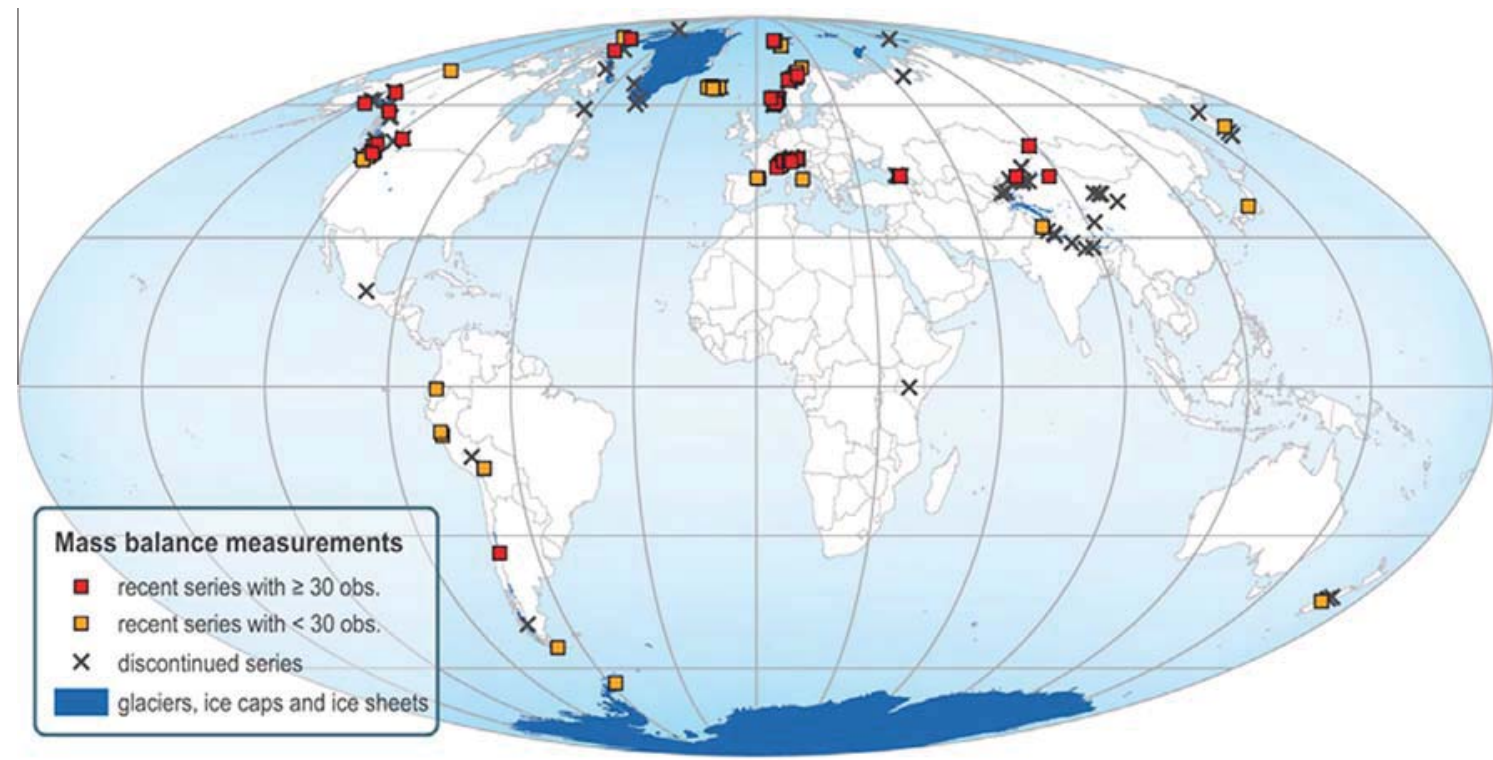

Fig. 3. Worldwide mass balance measurements. The map shows the location of ice bodies with reported direct measurements of the glacier mass balance. Data series with surveys after 1999 are plotted as red and orange squares when having more or equal and less than 30 observation years, respectively. The locations of observation series discontinued before 2000 are shown as black crosses. (For interpretation of the references to color in this figure legend, the reader is referred to the web version of this article.) Data source: WGMS (2008)

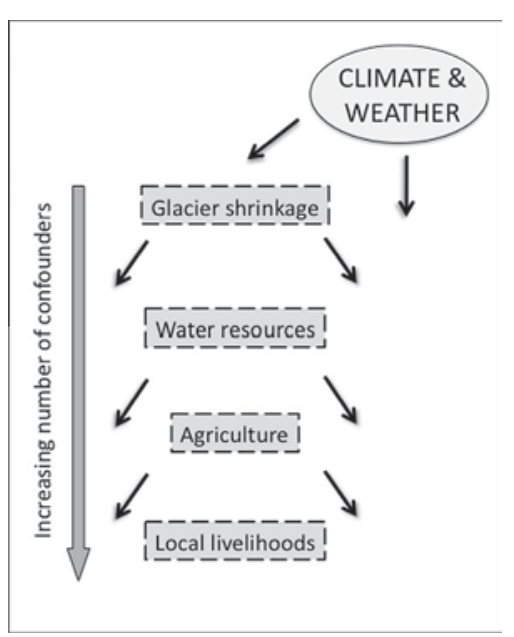

Fig. 4. Cascading impacts of climatic change at an example for high-mountain glaciers.

duration and specific data collection. While such data are highly valuable for the question addressed by the project, it is typically hardly usable as baseline data for guiding adaptation strategies.

\subsection{Snow}

In general, the impacts of climate change on snow regimes and therefore also on runoff have received much less attention than the impacts on glacial changes. As a consequence, the importance of runoff changes induced by altered snow regimes has possibly been underestimated in various environments, including several parts of the Greater Himalayas (Rohrer et al., 2013).

Compared to global glacier monitoring, measuring and monitoring of mountain snow has proven even more challenging. Due to the seasonal character of snow cover and its dependence on weather patterns, snow variables can be highly variable both in time and space, which substantially complicates the collection, measurement and analysis of snow parameters. Three snow variables are typically measured and also defined as Essential Climate Variables (ECV) by the Global Climate Observing System (GCOS); (i) snow cover extent (SCE), (ii) snow depth (SD), and (iii) snow water equivalent (SWE). For the amount and timing of runoff, SD and in particularly SWE are the most critical variables, but also the most fluctuating ones in time and space and therefore more challenging to measure; whereas SCE is more homogenously distributed annually, but of lower importance for runoff.

On a global scale, satellite-borne visible sensors operationally monitor SCE, and respective products are made available through the National Oceanic and Atmospheric Administration (NOAA) and include the Moderate Resolution Imaging Spectro-radiometer (MODIS) data with a resolution of ca. $500 \times 500 \mathrm{~m}$ (e.g. Hall et al., 2002). Other SCE-data products (for the northern hemisphere) are provided weekly since 1966 . Global monitoring of SD and SWE is unlikely more challenging. Satellite based observation is basically possible by microwave sensors, but is much more difficult in regions with high relief than over flat terrain. Whereas for the northern hemisphere (alpine areas masked out), SWE estimation by space borne sensors is now possible with root mean square errors below $40 \mathrm{~mm}$ for cases with SWE values below about $150 \mathrm{~mm}$ (Takala et al., 2011), these measurements are considerably more complicated in mountainous areas at all SWE values (Matzler and Standley, 2000; de Lannoy et al., 2012). As a consequence, at the global scale, long-term data and/or spatially representative data is scarce, particularly in mountain regions.

For SD and SWE, satellite-based observations are complemented by in situ point measurements. Automatic station that measure SD and SWE and 'hand-methods' are in use. New types of terrestrial laser scanners are operating in a wavelength where reflectivity of snow is very high, thus allowing to obtain high resolution (up to about $1 \mathrm{~m}$ cell size) air-borne or terrestrial pictures of spatial variability of the snow cover and its temporal evolution (e.g. Grünewald et al., 2010). As such, the repeated calculation of snow distribution maps for small catchments in the accumulation and ablation phase (e.g. Egli et al., 2012) becomes possible. 


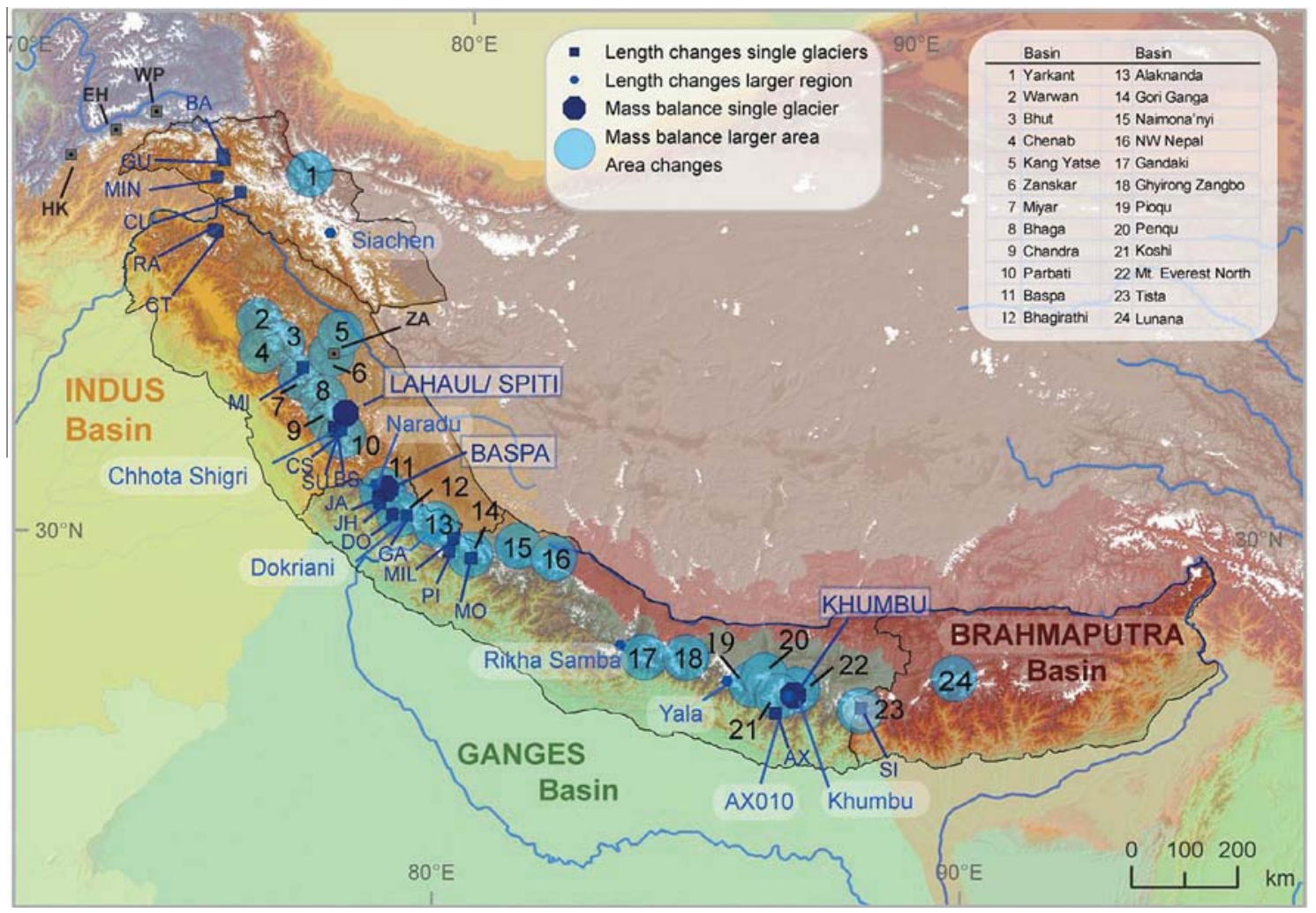

Fig. 5. Glacier monitoring sites along the Himalayan arc and at the headwaters of the major river basins. For abbreviations of single glacier length changes refer to Bolch et al., 2012 (modified from Bolch et al., 2012).

In several mountain ranges, large operational snow measurement networks are maintained, which however, are often primarily motivated by purposes other than climatic trend observations. In the Swiss Alps, a relatively dense network of more than 160 snow measurement stations is operated by the Swiss Federal Institute for Snow and Avalanche Research (SLF), primarily for use in avalanche warning. Since these measurements are neither verified nor corrected, they are not at a quality level needed for climatic trend analyses. Another example for a relatively dense snow station networks (over 730 sites) is SNOTEL (Snow Telemetry) in the U.S. Rocky Mountains. It was initially installed in the late 1970 s, primarily as a water-supply-forecasting hydroclimatic data collection network. Moreover, the used snow pillow instruments are usually located in forest openings. These are reasons, why SNOTEL sites are not necessarily distributed representative in space and regarding surface properties and for instance do not represent physiographic and snowpack conditions in a watershed, as shown by Molotch and Bales (2005) for the Rio Grande headwaters. Furthermore, a basic data quality check is done operationally, but data does not undergo a higher level of correction and/or homogenization, which hampers its use for temporal trend analyses.

As snow is an atmospheric variable, SWE and SD are also simulated by Reanalysis, Global Climate Models (GCM) and Regional Climate Models (RCM). Theses model outputs provide an interesting possibility for snow parameters and respective analyses (e.g. Steger et al., 2013), although at a relatively coarse spatial resolution for mountain topographies. However, Reanalysis and GCMs/ RCMs do not necessarily show skills in snow variables that are reliable and directly applicable at the local scale (Salzmann and Mearns, 2012), interposing statistical adjustment can nevertheless help to overcome some of the limitations (Rousselot et al., 2012).

\section{Identification of research and data gaps for adaptation practice}

This article centers on glacier, snow and related runoff data and research in mountain areas to be subsequently used for the science-based development of adaptation measures. The outline of research and data gaps presented in the following must thus be seen from this perspective. As a consequence, the objective here is to identify data and research gaps that hamper local understanding of climate change impacts and risks related to mountain snow and glacier runoff only, rather than to provide a comprehensive scientific analysis on gaps of snow and glacier research in general.

As outlined above, coordinated and internationally supported research on glacier and snow runoff usually focuses on global monitoring, large-scale modeling and related applications. Accordingly, data coverage and availability is relatively good overall at the global scale, although the quality of some variables is certainly not at the preferred level of quality and detail (e.g. SD and SWE). In addition, variables measured in situ are typically not optimally distributed in space and often biased towards easily accessible sites or densely populated and developed areas, which hampers a balanced analysis of individual parameters and thus affects the picture of spatial and temporal variability of trends.

Impacts of climate change are typically felt by society at the local scale, for instance through the occurrence of water shortage (Fraser, 2012) or cryospheric hazards such as glacier lake outburst floods (GLOFs; Worni et al., 2013). Adaptation measures thus need to be developed and implemented at the local level, and also need to consider the local societal context (e.g. Adger et al., 2003). Because of the local societal context and the spatial and temporal variability of trends (cf. Fig. 1), adaptation practice depends strongly on local-scale data and research. At this scale, however, 


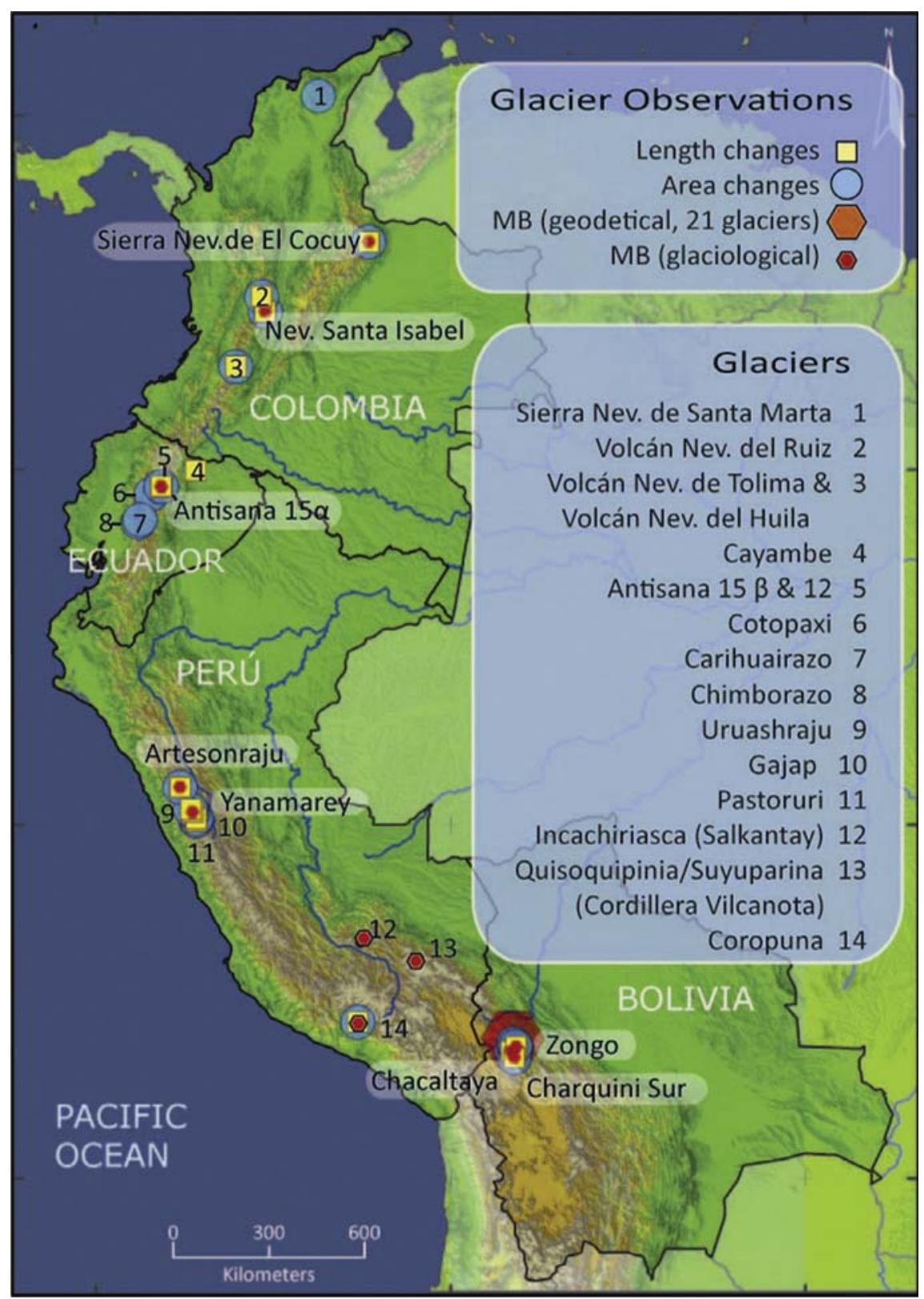

Fig. 6. Glaciers monitored in the Cordilleras of the tropical Andes. Glaciers with long-term mass balance series (small red hexagons) are labeled. For these glaciers, length (yellow cube) and area (blue circle) records also exist. In Bolivia, the large red hexagon depicts a sample of 21 glaciers in the Cordillera Real, for which mass balance reconstructions are available from 1963 to 2006 (Soruco et al., 2009a). Other glaciers whose changes in length and/or in area are monitored are numbered. (modified from Rabatel et al., 2013). (For interpretation of the references to color in this figure legend, the reader is referred to the web version of this article.)

glacier and snow data availability and data services, which provide and maintain this information is usually much less organized than the wealth of data handled by global-scale initiatives. In the framework of international initiatives, current efforts on data services focus mainly on weather and climate data, where national meteorological offices are about to taking over responsibility for these tasks and are supported for instance by the World Meteorological Organization (WMO) and GCOS through the creation of Regional Climate Centers.

The general lack of cryospheric observational data and data services at the local to regional scale has also been clearly identified as a major obstacle in various adaptation programs, where tremendous efforts had to be invested into the creation of reliable regional scientific baseline data as well as into the development of methods and tools that allow the generation of such data (Schauwecker et al., 2014; Salzmann et al., 2013; Schwarb et al., 2011).
(Long-term) data on local-scale processes are the fundament to understand ongoing processes and the related climate sensitivities, and to derive reliable trends for the past and hence plausible projections for the future. That is, above all, data and scientific investigations are needed to improve our process understanding and to allow for plausible assessments of the future evolution of snow and melt runoff and related impacts for the affected societies. In the following, we therefore outline a non-exhaustive selection of research and data needs in the fields of glacier, snow and related runoff that are critically required for the development of adaptation measures at the local scale.

Ice thickness is a basic number to calculate ice volumes and thus the presently stored amount of water in glaciers. Currently, there are several methods in use to estimate ice volumes (for an overview see Frey et al., 2013), however, only few cases exist where modeled thickness can be validated against measurements 
(e.g. Linsbauer et al., 2011; Farinotti et al., 2009). Techniques and methods to measure ice thickness are in principle available (e.g. Ground Penetrating Radar (Sold et al., 2013), but systematic measurements and data collection clearly remains at a case-study level for specific scientific projects and purposes.

Debris cover on glaciers can significantly control the energy and mass balance of a glacier and thus influence melt and runoff processes. The number and percentage of debris covered glaciers varies between regions, however, comparably large numbers are found in the Himalayas. Debris cover on glacier can be delineate relatively easily on satellite images, however, it is very time consuming. Studies on the effective influence of debris cover on the glacier mass balance and runoff are rare (e.g. Zhang et al., 2007, for the Tian Shan or Mayer et al., 2011, for the Altai mountains). A sensitivity study at Findelen glacier (Swiss Alps) has quantified the influence of debris cover on runoff (Huss et al., 2014), showing that debris cover is of minor importance for runoff. However, the results of this study cannot simply be transferred to other glaciers or other regions, and more investigations are needed to improve our understanding of the impacts of debris cover on runoff. Furthermore, to our knowledge, no models exist so far where future debris cover on a glacier can be simulated. Under certain circumstances (i.e. when associated with lakes), debris covered glacier can also retreat faster than debris-free glaciers, as shown e.g. by Basnett et al. (2013) for glaciers in the Sikkim Himalayas.

Mass balance measurements represent one component to learn about mass changes of a glacier. The dynamics of glaciers forms a second component that dictates runoff. To assess future runoff, the understanding of glacier dynamics must be further improved.

Albedo is a critical factor of the energy balance and thus for snow and ice melt processes (Oerlemans et al., 2009). Albedo values change when snow ages or when dusts are deposited. The latter, induced e.g. by anthropogenic emissions or through ice-cleared rock slopes, has the potential to change albedo values considerably; these changes need to be taken into account in work focusing on future changes. However, to date very few albedo measurements have been undertaken on glaciers or been made available. New approaches, including the use of spaceborne data, are currently being tested (e.g., Joerg et al., in revision; Naegeli et al., 2014).

Direct runoff measurements from specific glaciers are rare. Often, measurements are taken further downstream along rivers and where an attribution of changes in streamflow to individual runoff components (ice, snow, rain) is no longer feasible, because measurements performed at lower elevations do not represent true (natural) but disturbed runoff due to anthropogenic influences (e.g. by water taken for irrigation, power production, etc.). Moreover, the influence of permafrost on the hydrological regime is typically largely unknown, however can be an important factor, too (e.g. Qiu, 2012). Therefore, runoff model calibration is severely hampered and exact values for runoff and its changes over time become difficult to derive. For assessments of the impacts of glacier and snow changes on future runoff, however, streamflow data measured at their source are needed and with stations positioned directly at the glacier tongue.

To our knowledge, studies are also critically lacking with respect to the evaluation of the importance of SWE and SD at the catchment scale. Under changing climatic conditions, SWE and SD values will possibly be changing considerably, but so far the impacts of such changes on snow melt runoff have only been discussed in a few studies (e.g. López-Moreno et al., 2013a,b).

Important scientific knowledge needed in view of adaptation strategies includes the detailed understanding of the sensitivity of a process to changes of a specific climate variable such as in mean, maximum, or minimum air temperature, precipitation sums, intensity and frequency. Rates of change and the spatial patterns of change are equally important. While understanding of climate sensitivity is important to constrain global-scale climate models and produce plausible climate scenarios (Knutti and Tomassini, 2008), knowledge about the sensitivity of glaciers, snow and runoff to climatic changes is essential for impacts and adaptation at the local to regional scales.

In mountain regions, cascading climate impacts are particularly important (Fig. 4). Typically, the climate signal decreases from upstream to downstream locations, with a parallel increase of the influence of non-climatic factors, such as related to human activities (e.g. hydropower, agriculture, etc.). For instance, the final signal observed in river runoff at some downstream sections, represents the integrated signal of climate change and the influences of several confounding factors along the impacts cascade. For the purpose of adaptation it is important to analyze and disentangle the different driving factors, including the identification of the climate change signal. Such climate change detection and attribution research, however, is still poorly developed for the impacts level and needs to be strengthened in the future (Stone et al., 2013). This goal can only be achieved by substantial improvement in monitoring of key climate impact variables and processes, where glaciers, snow and runoff represent particularly important aspects in high-mountain regions. Long-term monitoring series (several decades) have an enormous value since they allow extracting climate signals from other confounding factors with higher confidence. Similarly, they contribute to understanding of climate sensitivity of specific processes, and thus provide more comprehensive baseline information for adaptation.

\section{Overcoming weaknesses}

In order to overcome the gaps in data and research identified above and to provide the scientific basis for sustainable adaptation measures, in the following we outline some possible directions of thinking with regard to options, which would also require considerable support from international bodies.

\subsection{Accessibility and distribution of data}

Although local-scale data is typically scarce, particularly in remote mountain regions, our experience suggests that quite often more data is available than one might have thought initially, both at national institutions or from national or international initiatives and bodies (e.g., Central Asia - glacier data from the Russian times). Therefore, mechanism and services should be supported that aim at making records of historical data visible and accessible (data sharing platforms) and that also provide resources to treat these data in a way that they become usable for climate impacts applications. Data that is typically difficult to access stems from past projects and programs that have not achieved systematic documentation. Although they often cover only 3-4 years, they can still be of importance. Funding agencies could possibly take a leading role here in as such as they could improve the situation by valuing and providing time for searching and treating available data to a project. Since this is a highly work-intensive effort, yet scientifically not extremely attractive, new schemes must come from funding agencies to support such work and to provide it with the necessary scientific weight. The situation today supports typically the production of modeling results, which, however, are of limited value without sound validation baseline data.

Furthermore, funding agencies could further support data availability by maintaining a database where data (metadata) is stored from previous projects. In this way, new projects could easily screen the kind of data already available for a certain region. Finally, funding agencies should also support monitoring efforts 
in order to generate homogenous long-term observational records and make them easy accessible and available.

\section{2. (Spatial) transferability}

Even if the desirable efforts described above should become reality, it is also clear that the possibilities of maintaining high density data networks have their limitations in terms of financial resources, but also in terms of accessibility of high mountain investigation sites. In order to make existing data most widely useful, the analysis and development of knowledge-based techniques to potentially transfer data, methods and research results between locations would be of high value. With transferability, we furthermore also refer to 'temporal' transferability, meaning that major data gaps that may have occurred for instance under specific political circumstances (e.g., the disintegration of the Soviet Union and the continuation of long-term measurements of Abromov glacier, Kyrgyzstan; Barandun et al., 2013 or in Peru (Schwarb et al., 2011; Salzmann et al., 2013)) or due to technical issues at high elevation sites with hindered accessibility can be filled.

\subsection{Collaboration and capacity building}

As adaptation and related data and research are needed at the local scale, the engagement of local support for long-term data and research activities becomes a prerequisite for any sustainable program. Therefore, collaboration with local research institutions is critical, but also difficult as the regions targeted by adaption are often remote, with the consequence that related research capacities can be low and only a limited number of persons bring the basic knowledge required to collect data and to conduct research. To maintain sustainability in monitoring and research at the highest possible level, capacity building is of key importance, and thus represents a component, which should be a major pillar of any initiative in this regard. In parallel, it is at least of similar importance to provide interesting perspective to (mostly) young researchers that are selected and willing to take a lead in these monitoring and research activities. Here, international programs can play a critical role, but local authorities need also to be convinced to invest into such long-term, high-effort-needed activities. The recently launched Indo-Swiss collaborative Indian Himalayas Climate Adaptation Programme (IH-CAP; http://www.ihcap.in) is such an initiative where capacity building of young Indian students is one of the key pillars of collaborative research. Similar programs are also ongoing in the Andes and other regions (Huggel et al., 2012).

\subsection{Long-term support for selected representative locations}

For most of the data and research needs identified above continued and long-term measurements are key to improve our understanding of changes and to adapt adequately to them. Local to regional long-term monitoring programs, similar to global programs, should also be supported and coordinated at the local scale through regional mountain centers/hubs. The current modalities of financing favor programs with a lifetime of 3-4 years, or in other words, have a clear focus on experimental research. To support sustainable programs and longer-term measurement series, funding agencies should aim at overcoming the creation of short and discontinued data series and create opportunities for researchers to collect such viable information over a reasonable time so that local process understanding on time scales relevant for adaptation measures can be achieved. Coordination among funding institutions and implementing government and science institutions should become a priority to create synergies and take full advantage of available resources.

\section{Conclusion and outlook}

Adaptation to adverse impacts of climate change is foremost a challenge that has to be tackled at the local or regional scale and within the societal context of the target region. Scientific disciplines that aim at considering needs by adaptation practitioners require a focus on local-scale process understanding of past, ongoing and future global changes. Furthermore, in terms of data and local knowledge, an improved coordination of research activities and data sharing as well as more longer-term observations are a prerequisite for the definition of plausible local- to regional-scale climate change impacts assessments, which in turn are the basis for any sound adaptation measures.

Large international funding agencies and programs could play a significant role in these fields and clearly represent the bodies, which would have the potential to support local-scale monitoring and the creation and maintenance of data services in a way they currently do at the global scale, and start to do at more regional scales for climate data. By doing so, there is also a need for new techniques and methods in snow and glacier measuring techniques to be systematically evaluated to render monitoring of these processes and the changes of these on runoff potentially more efficient.

Finally, interdisciplinary supported and integrative approaches should play an increasingly important role so as to understand and attribute observed changes in the system to causative factors.

\section{Acknowledgements}

We acknowledge collaboration and support by Marlene Scheel and Tobias Bolch for glacier monitoring information on the Andes and the Himalayas. We furthermore thank two anonymous reviewers for the helpful comments and suggestions. Finally, the authors acknowledge financial support by the Swiss Agency for Development and Cooperation (SDC).

\section{References}

Adger, W.N., Huq, S., Brown, K., Conway, D., Hulme, M., 2003. Adaptation to climate change in the developing world. Prog. Dev. Stud. 3, 179.

Arendt, A., Echelmeyer, K., Harrison, W.D., Lingle, G., Valentine, V., 2002. Rapid wastage of Alaska glaciers and their contribution to rising sea level. Science 297, 382-386.

Arendt, A., Bolch, T., Cogley, J.G., Gardner, A., Hagen, J.-O., Hock, R., Kaser, G., Pfeffer, W.T., Moholdt, G., Paul, F., Radić, V., Andreassen, L., Bajracharya, S., Barrand, N., Beedle, M., Berthier, E., Bhambri, R., Bliss, A., Brown, I., Burgess, D., Burgess, E., Cawkwell, F., Chinn, T., Copland, L., Davies, B., De Angelis, H., Dolgova, E., Filbert, K., Forester, R.R., Fountain, A., Frey, H., Giffen, B., Glasser, N., Gurney, S., Hagg, W., Hall, D., Haritashya, U.K., Hartmann, G., Helm, C., Herreid, S., Howat, I., Kapustin, G., Khromova, T., Kienholz, C., Köonig, M., Kohler, J., Kriegel, D. Kutuzov, S., Lavrentiev, I., Le Bris, R., Lund, J., Manley, W., Mayer, C., Miles, E., Li, X., Menounos, B., Mercer, A., Mölg, N., Mool, P., Nosenko, G., Negrete, A., Nuth, C., Pettersson, R., Racoviteanu, A., Ranzi, R., Rastner, P., Rau, F., Raup, B., Rich, J., Rott, H., Schneider, C., Seliverstov, Y., Sharp, M., Sigurðsson, O., Stokes, C., Wheate, R., Winsvold, S., Wolken, G., Wyatt, F., Zheltyhina, N., 2012. Randolph Glacier Inventory - A Dataset of Global Glacier Outlines: Version 3.2. Global Land Ice Measurements from Space, Boulder Colorado, USA, Digital Media.

Arendt, A., Luthcke, S., Gardner, A., O'Neel, S., Hill, D., Moholdt, G., Abdalati, W., 2013. Analysis of a GRACE global mascon solution for Gulf of Alaska glaciers. J. Glaciol. 59, 913

Baraer, M., Mark, B.G., McKenzie, J.M., Condom, T., Bury, J., Huh, K.-I., Portocarrero, C., Gómez, J., Rathay, S., 2012. Glacier recession and water resources in Peru's Cordillera Blanca. J. Glaciol. 58, 134-150.

Barandun, M., Huss, M., Azisov, E., Gafurov, A, Hoelzle, M. Merkushkin, A Salzmann, N., Usubaliev, R., 2013. Re-establishing seasonal mass balance observation at Abramov glacier, Kyrgyzstan, from 1968-2012. General Assembly European Geosciences Union, vol. 15, Vienna, Austria 2013, Geophysical Research Abstracts.

Barnett, T.P., Adam, J.C., Lettenmaier, D.P., 2005. Potential impacts of a warming climate on water availability in snow-dominated regions. Nature 438, 303-309.

Basnett, S., Kulkarni, A., Bolch, T., 2013. Influence of debris-cover and glacial lakes on the recession of glaciers in Sikkim Himalaya. India J. Glaciol. 95, 218.

Beniston, M., Stoffel, M., Hill, M., 2011. Impacts of climatic change on water and natural hazards in the Alps: can current water governance cope with future 
challenges? examples from the European "ACQWA" project. Environ. Sci. Pol. $14,734-743$

Bolch, T., Kulkarni, A., Kääb, A., Huggel, C., Paul, F., Cogley, J.G., Frey, H., Kargel, J.S Fujita, K., Scheel, M., Bajracharya, S., Stoffel, M., 2012. The state and fate of Himalayan glaciers. Science 336, 310-314.

Brown, R.D., Mote, P.W., 2009. The response of northern hemisphere snow cover to a changing climate. J. Clim. 22, 2124-2145.

Brutel-Vuilmet, C. Ménégoz, M., Krinner, G., 2013. An analysis of present and future seasonal Northern Hemisphere land snow cover simulated by CMIP5 coupled climate models. Cryosphere 7 (1), 67-80, 7, 67-80.

Christensen, N., Wood, A.W., Voisin, N., Lettenmaier, D.P., Palmer, N., 2004. The effect of climate change on the hydrology and water resources of the Colorado River basin. Clim. Change 62, 337-363.

Collins, D.N., 2006. Climatic variation and runoff in mountain basins with differing proportions of glacier cover. Nord. Hydrol. 37, 315-326.

Collins, D.N., Davenport, J.L., Stoffel, M., 2013. Climatic variation and runoff from partially-glacierized Himalayan tributary basins of the Ganges. Sci. Total Environ. 468-469 (Suppl.), S48-S59.

De Lannoy, G.J.M., Reichle, R.H., Arsenault, K.R., Houser, P.R., Kumar, S., Verhoest, N.E.C., Pauwels, V.R.N., 2012. Multiscale assimilation of advanced microwave scanning radiometer-EOS snow water equivalent and moderate resolution imaging spectroradiometer snow cover fraction observations in northern Colorado. Water Resour. Res. 48, W01522. http://dx.doi.org/10.1029/ 2011 wr010588.

Déry, S.J., Brown, R.D., 2007. Recent Northern Hemisphere snow cover extent trends and implications for the snow-albedo feedback. Geophys. Res. Lett. 34 6(L22504).

Egli, L., Jonas, T., Grünewald, T., Schirmer, M., Burlando, P., 2012. Dynamics of snow ablation in a small Alpine catchment observed by repeated terrestrial lase scans. Hydrol. Process. 26, 1574-1585.

Farinotti, D., Huss, M., Bauder, A., Funk, M., Truffer, M., 2009. A method to estimate the ice volume and ice-thickness distribution of alpine glaciers. J. Glaciol., 422 430, 4815, 4820, 4821, 4823.

Finger, D., Heinrich, G., Gobiet, A., Bauder, A., 2012. Projections of future water resources and their uncertainty in a glacierized catchment in the Swiss Alps and the subsequent effects on hydropower production during the 21st century. Water Resour. Res. 48, 20.

Fraser, B., 2012. Melting in the Andes: goodbye glaciers. Nature 491, 180-182.

Frey, H., Machguth, H., Huss, M., Huggel, C., Bajracharya, S., Bolch, T., Kulkarni, A. Linsbauer, A., Salzmann, N., Stoffel, M., 2013. Ice volume estimates for the Himalaya-Karakoram region: evaluating different methods. Cryosphere Discuss. 7, 4813-4854.

Gardner, A.S., Moholdt, G., Cogley, J.G., Wouters, B., Arendt, A.A., Wahr, J., Berthier E., Hock, R., Pfeffer, W.T., Kaser, G., Ligtenberg, S.R.M., Bolch, T., Sharp, M.J. Hagen, J.O., Broeke, M.R., van den, Paul, F., 2013. A reconciled estimate of glacier contributions to sea level rise: 2003-2009. Science 340, 852-857.

Grünewald, T., Schirmer, M., Mott, R., Lehning, M., 2010. Spatial and tempora variability of snow depth and ablation rates in a small mountain catchment. Cryosphere 4, 215-225.

Hall, D.K. Riggs, G.A., Salomonson, V.V., Digirolamo, N.E., Bayr, K.J., 2002. MODIS snow-cover products. Remote Sens. Environ. 83, 181-194.

Henderson, G.R., Leathers, D.J., 2010. European snow cover extent variability and associations with atmospheric forcings. Int. J. Clim. 30, 1440-1451.

Hock, R., 2003. Temperature index melt modeling in mountain areas. J. Hydrol. 282 104-115.

Huggel, C., Cochachin, A., Frey, H., García, J., Giráldez, C., Gómez, J., Haeberli, W., Ludeña, S., Portocarrero, C., Price, K., Rohrer, M., Salzmann, N., Schleiss, A., Schneider, D., Silvestre, E., 2012. Integrated assessment of high mountain hazards, related risk reduction and climate change adaptation strategies in the Peruvian Cordilleras. IDRC Davos 2012, Switzerland.

Huss, M., Farinotti, D., 2012. Distributed ice thickness and volume of all glaciers around the globe. J. Geophys. Res. 117, F04010. http://dx.doi.org/10.1029/ 2012JF002523.

Huss, M., Farinotti, D., Bauder, A., Funk, M., 2008. Modeling runoff from highly glacierized alpine drainage basins in a changing climate. Hydrol. Process. 22 3888-3902.

Huss, M., Zemp, M., Joerg, P.C., Salzmann, N., 2014. High uncertainty in 21st century runoff projections from glacierized basins. J. Hydrol. 510, 35-48. http:// dx.doi.org/10.1016/j.jhydrol.2013.12.017.

IPCC, 2013. Climate Change 2013: The Physical Science Basis. Contribution of Working Group I to the Fifth Assessment Report of the Intergovernmental Panel on Climate Change. In: Stocker, T.F., Qin, D., Plattner, G.-K., Tignor, M., Allen, S.K. Boschung, J., Nauels, A., Xia, Y., Bex, V., Midgley, P.M., (Eds.), International Organization for Standardization Standard Atmosphere, ISO 2533, Cambridge University Press, Cambridge, United Kingdom and New York, NY, USA, 1535, pp. ISO (1975).

Jacob, T., Wahr, J., Pfeffer, W.T., Swenson, S., 2012. Recent contributions of glaciers and ice caps to sea level rise. Nature 482, 514-518.

Joerg, P.C., Weyermann, J., Morsdorf, F., Zemp, M., Schaepman, M.E., in revision. Computation of a distributed glacier surface albedo using airborne laser scanning intensity data and in situ spectro-radiometric measurements. Remote Sens. Environ.

Kääb, A., Berthier, E., Nuth, C., Gardelle, J., Arnaud, Y., 2012. Contrasting patterns of early twenty-first-century glacier mass change in the Himalayas. Nature 488 , 495-498.
Kamforsud-Supsi, 2012. Moving down or not. In: Part 1: -Synthesis Report. Kam for -Sud and University of Applied Sciences of Southern Switzerland (SUPSI), p. 77. <http://ita.kamforsud.org/wp-content/uploads/PartI Synthesis.pdf>.

Knutti, R., Tomassini, L., 2008. Constraints on the transient climate response from observed global temperature and ocean heat uptake. Geophys. Res. Lett. 35, L09701.

Linsbauer, A., Paul, F., Haeberli, W., 2011. Modeling glacier thickness distribution and bed topography over entire mountain ranges with GlabTop: application of a fast and robust approach. J. Geophys. Res. 117, F03007. http://dx.doi.org/ 10.1029/2011JF002313, 2012. 4820, 4821, 4822.

López-Moreno, J.I., Pomeroy, J.W., Revuelto, J., Vicente-Serrano, S.M., 2013a. Response of snow processes to climate change: spatial variability in a small basin in the Spanish Pyrenees. Hydrolo. Process. 27 (18), 2637-2650. http:// dx.doi.org/10.1002/hyp.9408.

López-Moreno, J.I., Revuelto, J., Gilaberte, M., Morán-Tejeda, E., Pons, M., Jover, E., Esteban, P., García, C., Pomeroy, J.W., 2013b. The effect of slope aspect on the response of snowpack to climate warming in the Pyrenees. Theor. Appl. Climatol., 1-13. http://dx.doi.org/10.1007/s00704-013-0991-0.

Machguth, H., Eisen, O., Paul, F., Hoelzle, M., 2006. Strong spatial variability of snow accumulation observed with helicopter-borne GPR on two adjacent Alpine glaciers. Geophys. Res. Lett. 33, L13503.

Marty, C., 2008. Regime shift of snow days in Switzerland. Geophys. Res. Lett. 35, L12501.

Marzeion, B., Jarosch, A.H., Hofer, M., 2012. Past and future sea-level change from the surface mass balance of glaciers. Cryosphere 6, 1295-1322.

Matzler, C., Standley, A., 2000. Relief effects for passive microwave remote sensing. Int. J. Remote Sens, 21, 2403-2412.

Mayer, C., Lambrecht, A., Hagg, W., Narozhny, Y., 2011. Glacial debris cover and melt water production for glaciers in the Altay, Russia. Cryosphere Discuss. 5, 401-430.

Molotch, N.P., Bales, R.C., 2005. Scaling snow observations from the point to the grid element: Implications for observation network design. Water Resour. Res. 41 (W11421), 2005W. http://dx.doi.org/10.1029/R004229.

Moors, E.J., Stoffel, M., 2013. Changing monsoon patterns, snow and glacial melt, its impacts and adaptation options in northern India: Synthesis. Sci. Total Environ. 468-469, S162-S167.

Naegeli, K., Huss, M., Damm, A., de Jong, R., Schaepman, M., Hoelzle, M., 2014 Imaging spectroscopy to assess the composition of ice surface materials and their impact on glacier mass balance. Geophys. Res. Abstr. 16, EGU2014-6282.

Oerlemans, J., Giesen, R.H., Van Den Broeke, M.R., 2009. Retreating alpine glaciers: increased melt rates due to accumulation of dust (Vadret da Morteratsch, Switzerland). J. Glaciol. 55, 729-736.

Paul, F., Bolch, T., Kääb, A., Nagler, T., Nuth, C., Scharrer, K., Shepherd, A., Strozzi, T., Ticconi, F., Bhambri, R., Berthier, E., Bevan, S., Gourmelen, N., Heid, T., Jeong, S. Kunz, M., Lauknes, T.R., Luckman, A., Merryman, J., Moholdt, G., Muir, A. Neelmeijer, J., Rankl, M., VanLooy, J., Van Niel, T., in press. The glaciers climate change initiative: Methods for creating glacier area, elevation change and velocity products. Remote Sens. Environ.

Pellicciotti, F., Carenzo, M., Bordoy, R., Stoffel, M., 2014a. Changes in glaciers in the Swiss Alps and impact on basin hydrology: current state of the art and future research. Sci. Total Environ. in press http://dx.doi.org/10.1016/j.scitotenv. 2014.04.022

Pellicciotti, F., Ragettli, S., Carenzo, M., McPhee, J., 2014b. Changes of glaciers in the Andes of Chile and priorities for future work. Sci. Total Environ. in press http:// dx.doi.org/j.scitotenv.2013.10.055

Qiu, J., 2012. Thawing permafrost reduces river runoff. Nature. http://dx.doi.org/ 10.1038/nature.2012.9749.

Rabatel, A., Francou, B., Soruco, A., Gomez, J., Cáceres, B., Ceballos, J.L., Basantes, R. Vuille, M., Sicart, J.-E., Huggel, C., Scheel, M., Lejeune, Y., Arnaud, Y., Collet, M., Condom, T. Consoli, G., Favier, V., Jomelli, V., Galarraga, R, Ginot, P., Maisincho, L., Mendoza, J., Ménégoz, M., Ramirez, E., Ribstein, P., Suarez, W., Villacis, M., Wagnon, P., 2013. Current state of glaciers in the tropical Andes: a multicentury perspective on glacier evolution and climate change. Cryosphere 7 , 81-102.

Rohrer, M., Salzmann, N., Stoffel, M., Kulkarni, A., V., 2013. Missing (in situ) snow cover data hampers climate change and runoff studies in the greater Himalayas. Sci. Total Environ. 468-469 (Suppl.), S60-S70.

Rousselot, M., Durand, Y., Giraud, G., Mérindol, L., Dombrowski-Etchevers, I., Déqué, M., Castebrunet, H., 2012. Statistical adaptation of ALADIN RCM outputs over the French Alps - application to future climate and snow cover. Cryosphere 6 , 785-805.

Salzmann, N., Mearns, L.O., 2012. Assessing the performance of multiple regional climate model simulations for seasonal mountain snow in the upper Colorado River Basin. J. Hydrometeorol. 13, 539-556 (Accessed 12.11.2013).

Salzmann, N., Huggel, C., Calanca, P., Diaz, A., Jonas, T., Jurt, C., Konzelmann, T., Lagos, P., Rohrer, M., Silverio, W., Zappa, M., 2009. Integrated assessment and adaptation to climate change impacts in the Peruvian Andes. Adv. Geosci. 22 41-49.

Salzmann, N., Machguth, H., Linsbauer, A., 2012. The Swiss Alpine glaciers' response to the global "2 \& \#xB0;C air temperature target". Environ. Res. Lett. 7, 044001.

Salzmann, N., Huggel, C., Rohrer, M., Silverio, W., Mark, B.G., Burns, P., Portocarrero, C. 2013. Glacier changes and climate trends derived from multiple sources in the data scarce Cordillera Vilcanota region, southern Peruvian Andes. Cryosphere 7, 103-118. 
Schwarb, M., Acuña, D., Konzelmann, T., Rohrer, M., Salzmann, N., Serpa Lopez, B., Silvestre, E., 2011. A data portal for regional climatic trend analysis in a Peruvian High Andes region. Adv. Sci. Res. 6, 219-226.

Schauwecker, S., Rohrer, M., Acuña, D., Cochachin, A., Dávila, L., Frey, H., Giráldez, C., Gómez, J., Huggel, C., Jacques-Coper, M., Loarte, E., Salzmann, N., Vuille, M., 2014. Climate trends and glacier retreat in the Cordillera Blanca, Peru, revisited. Glob. Plan. Change 119, 85-97.

Sold, L., Huss, M., Hoelzle, M., Andereggen, H., Joerg, P.C., Zemp, M., 2013. Methodological approaches to infer end-of-winter snow distribution on alpine glaciers. J. Glaciol. 59 (218), 1047-1059. http://dx.doi.org/10.3189/ 2013JoG13J015.

Sorg, A., Bolch, T., Stoffel, M., Solomina, O., Beniston, M., 2012. Climate change impacts on glaciers and runoff in Central Asia. Nature Clim. Change 2 (10), 725-731.

Sorg, A., Mosello, B., Shalpykova, G., Allan, A., Hill, M., Stoffel, M., in press. Coping with changing water resources: The case of the Syr Darya river basin in Central Asia. Environ. Sci. Policy. http://dx.doi.org/10.1016/j.envsci.2013.11.003

Soruco, A., Vincent, C., Francou, B., Gonzalez, J.F., 2009. Glacier decline between 1963 and 2006 in the Cordillera Real, Bolivia. Geophys. Res. Lett., 36.

Steger, C., Kotlarski, S., Jonas, T., Schär, C., 2013. Alpine snow cover in a changing climate: a regional climate model perspective. Clim. Dyn. 41, 735-754.

Stone, D., Auffhammer, M., Carey, M., Hansen, G., Huggel, C., Cramer, W., Lobell, D., Molau, U., Solow, A., Tibig, L., Yohe, G., 2013. The challenge to detect and attribute effects of climate change on human and natural systems. Clim. Change, $1-15$.

Strozzi, T., Kouraev, A., Wiesmann, A., Wegmüller, U., Sharov, A., Werner, C., 2008. Estimation of Arctic glacier motion with satellite L-band SAR data. Remote Sens. Environ. 112, 636-645.

Takala, M., Luojus, K., Pulliainen, J., Derksen, C., Lemmetyinen, J., Kärnä, J.-P., Koskinen, J., Bojkov, B., 2011. Estimating northern hemisphere snow water equivalent for climate research through assimilation of space-borne radiometer data and ground-based measurements. Remote Sens. Environ. 115 (12), 3517-3529.

Vergara, W., Deeb, A.M., Valencia, A.M., Bradley, R.S., Francou, B., Zarzar, A. Grünwaldt, A., Haeussling, S.M., 2007. Economic impacts of rapid glacier retreat in the Andes. EOS Trans. Am. Geophys. Union 88, 261.

Viviroli, D., Dürr, H.H., Messerli, B., Meybeck, M., Weingartner, R., 2007. Mountains of the world, water towers for humanity: typology, mapping, and global significance. Water Resour. Res., 43.

Viviroli, D., Archer, D., Buytaert, W., Fowler, H., Greenwood, G., Hamlet, A., Huang, Y., Koboltschnig, G., Litaor, M., López-Moreno, J., et al., 2011. Climate change and mountain water resources: overview and recommendations for research, management and policy. Hydrol. Earth Syst. Sci. 15, 471-504.

Voigt, T., Füssel, H.-M., Gärtner-Roer, I., Huggel, C., Marty, C., Zemp, M., 2011. Impacts of Climate Change on Snow, Ice, and Permafrost in Europe: Observed Trends, Future Projections, and Socio-Economic Relevance. European Environment Agency, Copenhagen.

Vorogushyn, S. Bens, O., Merz, B., Reigber, Ch., Moldobekov, B., Helm, A., Oberhänsli, H., Küppers, A., Rössner, S., Güntner, A., 2008. The regional research network project " Water in Central Asia" (CAWa): status quo and future perspectives. In: Symposium in Memory of the 80th Anniversary of the German - Russian Alay/ Pamir Expedition in 1928, Tashkent, Uzbekistan.

WGMS (2008): Global Glacier Changes: facts and figures. Zemp, M., Roer, I., Kääb, A., Hoelzle, M., Paul, F. and Haeberli, W. (eds.), UNEP, World Glacier Monitoring Service, Zurich, Switzerland: 88 pp.

Worni, R., Huggel, C., Stoffel, M., 2013. Glacier lakes in the Indian Himalayas glacier lake inventory, on-site assessment and modeling of critical glacier lakes. Sci. Total Environ., 468-469, S71-S84.

Zhang, Y., Liu, S., Ding, Y., 2007. Glacier meltwater and runoff modeling, Keqicar Baqi glacier, southwestern Tien Shan. China J. Glaciol. 53 (180), 91-98. 